\title{
Oxfordian microbial laminites from La Manga Formation, Neuquén Basin, Argentina: Remarkable nanobacteria preservation
}

\author{
R.M. Palma ${ }^{1 *}$, D.A. Kietzmann ${ }^{1}$, M. Comerio ${ }^{1,2}$, J. Martín-Chivelet ${ }^{3,4}$, J. López-Gómez ${ }^{4}$, G.S. Bressan ${ }^{1}$ \\ ${ }^{1}$ Universidad de Buenos Aires, Facultad de Ciencias Exactas y Naturales, Dept. de Ciencias Geológicas -CONICET-IDEAN. Argentina. \\ ${ }^{2}$ CETMIC, C.C. 49, Manuel B. Gonnet, La Plata. Argentina. \\ ${ }^{3}$ Departamento de Estratigrafí, Facultad de Ciencias Geológicas, Universidad Complutense de Madrid, 28040 Madrid, Spain \\ ${ }^{4}$ Instituto de Geociencias (CSIC, UCM). C/ José Antonio Nováis 12, 28040 Madrid, Spain
}

e-mail addresses: palma@gl.fcen.uba.ar (RMP, *Corresponding author); diegokietzmann@gl.fcen.uba.ar (DAK); comerio@gl.fcen.uba.ar (C.C.); martinch@ucm.es (JMC); jlopez@geo.ucm.es(JLG)

Received: 22 September 2015 / Accepted: 20 November 2015 / Available online: 20 December 2015

\begin{abstract}
Exceptionally preserved stromatolites have been found in the shallow marine carbonate facies of the Callovian-Oxfordian La Manga Formation, in the Neuquén Basin (Argentina). The stromatolites exhibit planar and crinkle lamination, often disrupted by sheet-cracks, mudcracks, and fenestral structures, which indicate periodic subaerial exposure. These and other evidences suggest that these stromatolites grew in low energy upper intertidal to lower supratidal environments. They consist of fine micrite/microsparite crystal fabrics (with a remarkable lack of allochems) that define submillimiter alternations of dense laminae. Extensive SEM examinations of polished samples of the stromatolites reveal exceptional preservation of rod-shaped bacteria, coccoid like microorganisms, and abundant aggregates of framboidal pyrite.

The rod-like bacteria consists of a network of irregular distributed filaments, which range from $150 \mathrm{~nm}$ to an uncommon $640 \mathrm{~nm}$ in length; diameters range from $54 \mathrm{~nm}$ to $90 \mathrm{~nm}$. Subspherical bodies range in size between 70 and $89 \mathrm{~nm}$. The presence of abundant framboidal pyrites is interpreted as the result of the metabolic activity of sulfate-reducing bacteria and decay of organic matter.
\end{abstract}

Keywords: stromatolite, nanobacteria, Jurassic, Neuquén Basin, Argentina

\section{Resumen}

Se describen estromatolitos excepcionalmente preservados en facies carbonáticas marinas someras en la Formación La Manga, de edad Calloviense-Oxfordiense, en la Cuenca de Neuquén (Argentina). Los estromatolitos muestran una laminación tanto planar como ondulada, frecuentemente alterada por estructuras de tipo fenestral, y sheet y mud-crack, que indican etapas de exposición subaérea. Estas y otras características sugieren que estos estromatolitos crecieron en ambientes de baja energía, intermareales altos y supramareales. Están constituidos por una fábrica de micrita-microesparita (con una destacada ausencia de aloquímicos) que constituyen alternancias submilimétricas de laminación densa. Estudios detallados con SEM sobre muestras pulidas revelan una preservación excepcional con morfología alargada, microorganismos tipo cocoide, y abundantes agregados de pirita framboidal.

Las bacterias con morfologías alargadas están constituyendo una red irregularmente distribuida de filamentos que oscilan en tamaño desde $150 \mathrm{~nm}$ hasta, excepcionalmente, $640 \mathrm{~nm}$ en longitud; el diámetro oscila entre $50 \mathrm{~nm}$ y $90 \mathrm{~nm}$. Las morfologías subesféricas oscilan entre $70 \mathrm{~nm}$ y $89 \mathrm{~nm}$. La presencia de abundantes piritas framboidales es interpretada como resultado de una actividad metabólica de bacterias sulfato-reductoras y la descomposición de materia orgánica.

Palabras clave: estromatolito, nanobacteria, Jurásico, Cuenca Neuquina, Argentina

\section{Introduction}

A renovated interest in the study of stromatolites rose from the new interdisciplinary approaches of geobiology dealing with biomineralization and microbe-mineral interactions (e.g., Reid et al., 2000; Weiner and Dove, 2003; Franke and Bazylinski, 2003; Visscher and Stolz, 2005; Dupraz et al., 2009; Spadafora et al., 2010). These frontier studies, which are based in modern settings including open marine, freshwater, alkaline lake, hypersaline, and hot spring environments, 
should give some keys for interpreting the past since the origins of life in Earth. In fact, these microbial carbonates are widespread throughout the geological record (e.g., Riding, 2000; Flügel, 2004), and have been easily recognized both in the field and in thin sections by generations of geologists because their distinctive morphology and defining lamination. However, these fossil stromatolites rarely preserve evidences of the microbial communities responsible of their formation and growth, an aspect which hampered their genetic interpretation and, in particular, the characterization of the microbial activity. In this paper, we present a case study of ancient peritidal stromatolites showing exceptional preservation of the forming microbial communities, which should help in building bridges between the new findings in modern stromatolites and their fossil counterparts. These have been found in the peritidal carbonates of the Callovian-Oxfordian La Manga Formation, in the Neuquén Basin (Argentina), which correspond to the shallowest facies of a wide carbonate ramp (Palma et al., 2007, 2009, 2010, 2013). The remarkable stromatolite preservation observed in different sedimentary sections allows for the recognition of macro and microfeatures, as well as the reconstruction of growth fabrics, laminae variations, the exceptional preservation of microbial communities including rod-like bacteria.

\section{Geological setting}

Located at the west margin of the South American platform, the Neuquén Basin is limited by a magmatic arc to the west and a tectonic foreland to the east (Fig. 1). The foreland consists of the Sierra Pintada belt to the northeast and the North Patagonian massif to the south. It is a typical retro-arc basin developed to the east of the Cordillera Principal between $36^{\circ} \mathrm{S}$ and $39^{\circ} \mathrm{S}$. Mitchum and Uliana (1985), Legarreta and Gulisano (1989), and Vergani et al. (1995) provide extensive information on the geologic setting of the region.

The carbonate platform of the La Manga Fm. constitutes most of the sedimentary record of the Callovian-Oxfordian in the Neuquén Basin. It represents the middle part of the Lotena Mesosequence, which mainly consists of carbonates with interbedded shales, marls, and occasional sandstones (Fig. 2).

Based on detailed stratigraphic work in the stratotype section (La Manga Creek, Mendoza), the depositional environment of La Manga Fm led to identification of two informal units. Unit 1 was deposited in an outer ramp setting, while deposition of unit 2 took place in intertidal-supratidal environments.

The sharp contact between the outer ramp facies of unit 1 and the overlying intertidal-supratidal facies of unit 2 can be
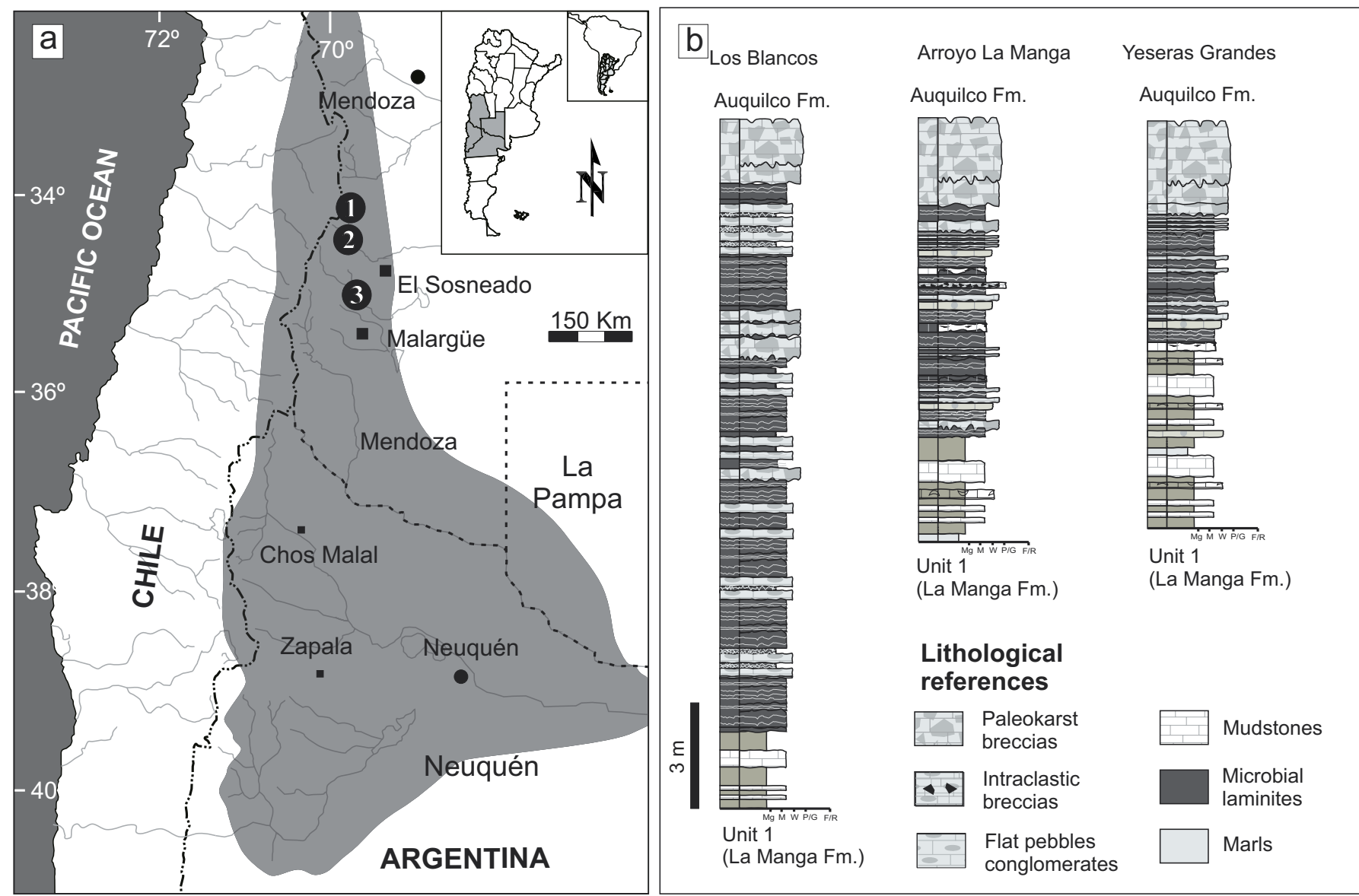

Fig. 1.- a) Location map of the Neuquén basin with indication of the studied localities (1. Yeseras Grandes; 2. Arroyo La Manga; 3. Arroyo Los Blancos), b) Simplified lithological columns showing the section corresponding to the peritidal facies that contain the stromatolite levels in the La Manga Fm. 


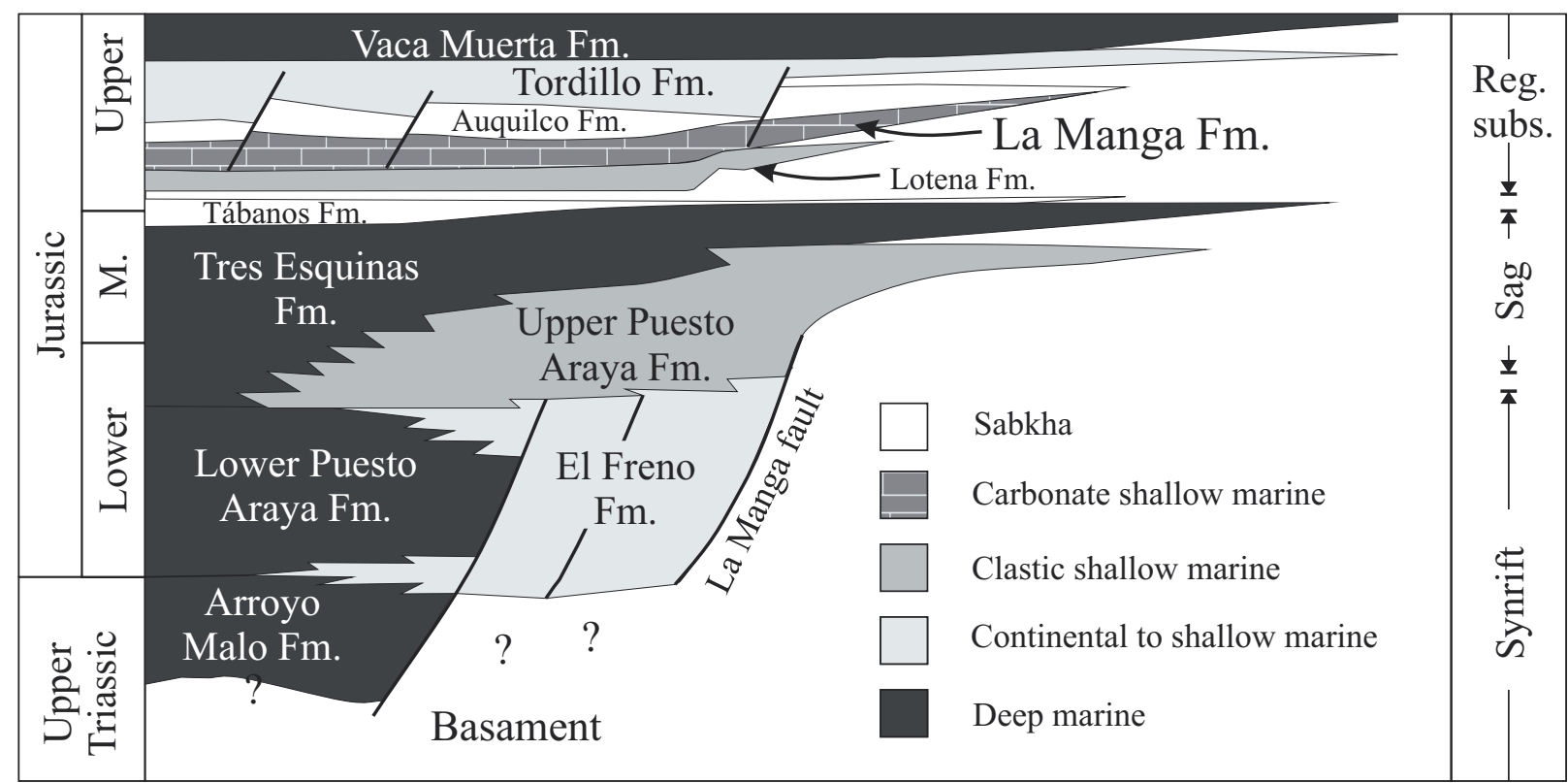

Fig. 2.- Jurassic lithostratigraphy of the Neuquén Basin in the Atuel depocenter, south of the Mendoza province (modified from Giambigi et al., 2008).

interpreted as the result of an abrupt fall (forced regression) of the relative sea level during the end of Middle Oxfordian or Upper Oxfordian.

Detailed sedimentological and biostratigraphic studies (Palma et al., 2007, 2009, 2010, 2012, 2013) allow to interpret facies and sedimentary environments not previously described for this unit. In the present study, the stromatolites were sampled from the upper part of the sequence, in the socalled Unit 2 by Palma et al. (2010). They are best exposed and best preserved at the Arroyo Los Blancos, La Manga and Yeseras Grandes sections (Fig. 1a-b), where the Unit 2 has $23 \mathrm{~m}, 12 \mathrm{~m}$, and $12 \mathrm{~m}$ in thickness respectively.

The age of the La Manga Fm. in the studied localities has been determined on the basis of ammonites and coccolithophorids. The former include Mirosphinctes sp. that could appear in the Middle Oxfordian as well as in the Upper Oxfordian (Palma et al., 2012). The presence of the coccolithophorid Cyclagelosphaera sp. indicates a Middle Oxfordian age (Concheyro, pers. comm.).

\section{Methods}

Standard thin sections of the stromatolites for conventional microscopic analysis were taken from the indicated sections. In order to recognize the mineralogy, X-ray diffraction patterns were carried out on a Philips 3020 goniometer (Ni-filtered $\mathrm{CuK \alpha}, 35 \mathrm{Kv}, 40 \mathrm{Ma}$, without secondary monochromator). Focusing on carbonates mineral phases present in the samples, non-oriented step-scan data were taken from 20 to $70^{\circ} 2 \theta$, with a step width of $0.04^{\circ}$ and a counting time of $2 \mathrm{~s} /$ step.

Carbonates mineral and other crystalline phases identified on the powder diffraction patterns were analyzed with the FULLPROF program, which is a multipurpose profile-fitting program including Rietveld refinement (Rodríguez Caravajal, 2001). The Rietveld method (Rietveld, 1969) was used for quantitative determination of the mineral phases present in the samples. The starting crystallographic data used for each mineral were extracted from the literature.

Scanning electron microscope (SEM) investigations were performed on fresh broken surfaces and on polished carbon coated thin sections, using a Zeiss (Supra 40) scanning electronic microscope with an Oxford Instruments EDS energy dispersive spectroscopy detector (INCA) for elemental analysis. These instruments are housed at the Centro de Microscopía Electrónica in the Facultad de Ciencias Exactas y Naturales, Universidad de Buenos Aires, Argentina.

\section{Oxfordian microbial laminites}

\subsection{Macro and mesostructure}

For examining the stromatolitic microbial fabric at different scales (macro-meso- and microstructural) we followed Shapiro (2000). The stromatolitic beds are 2 to $80 \mathrm{~cm}$ thick and have been recognized in all the studied sections, however, they are particularly abundant in Los Blancos section. The typical macrostructure is tabular, while the mesostructure ranges from planar to crinkle laminated (Fig. 3a-c). It is important to have in mind that remarkable domal forms are absent and that no preferred orientation of the stromatolites were observed.

Two main facies have been defined in the stromatolites: light grey microbial stromatolite with generally planar lamination, and crinkle laminated stromatolite beds (Fig. $3 \mathrm{a}-\mathrm{c})$. The stromatolites are closely related to mudstone and wackestones facies, as well as to flat-pebbles conglomerates and intraclastic breccias (Palma et al., 2012, 2013). 
In both types of stromatolite facies, laminae appear to have been partially turn-up, while still in a soft nonlithified state. Similar characteristics were observed on modern cyanobacterial flats in the intertidal to supatidal zone (Friedman et al., 1985).

Planar types (Fig. 3a-b): They are well represented in all the studied sections. They occur as 2 to $80 \mathrm{~cm}$ thick beds separated by 8 to $15 \mathrm{~cm}$ thick mudstone-wackestones or flatpebble conglomerates. On top of the stromatolites, bedding planes with some irregular crinkled relieve are present, as well as some bioturbation assigned to Scolicia isp? and frequent fenestrae and desiccation cracks (Fig. 3b).

Crinkle type (Fig. 3c): This type of stromatolite is also well represented in all sedimentary sections. They occur as approximately 7 to $12 \mathrm{~cm}$ thick beds. Mud-cracks, sheetcracks, fenestrae and tepee structures are common (Fig. $3 \mathrm{c})$. Tepees are characterized by small antiform deformation structures and reach 5 to $10 \mathrm{~cm}$ in thickness. They are associated with planar stromatolites, flat-pebble conglomerates and/or intraclastic breccia associated facies.

Flat-pebble conglomerates are the most common associated facies. It consists of rip-up clasts derived from underlying planar to crinkle stromatolite beds. Textures range from clast- to matrix-supported, and its thickness varies between 4 and $30 \mathrm{~cm}$. They are commonly associated with desiccation mud-cracks and tepees. Subangular to angular planar stromatolite intraclasts associated facies appear parallel, discontinuous or continuous to bedding. Nevertheless, in many cases, these intraclasts are randomly distributed or may have a slight imbrication.

\subsection{Microstructure}

The internal architecture of the stromatolites is rather simple. In terms of lamination patterns the stromatolites are classified into two groups: stromatolites with dominant planar lamination ("planar laminites") (Fig. 3b), and stromatolites with crinkle lamination ("crinkle laminites") (Fig. 3d).

Planar laminites (Fig. 3b) are composed of sheets of continuous laminae characterized by the alternation of dark submillimeter to up to $2 \mathrm{~mm}$ in thickness micritic laminae, with intercalated millimeter microsparitic laminae ranging in thickness between 3 to $13 \mathrm{~mm}$. Micrite appears as clotted or peloidal or as homogenous micrite. Occasionally, the laminae built up into millimeter convex-up dome (up to $15 \mathrm{~mm}$ high) growing on the planar or wavy surface (Fig. 3e). Changes in thickness from lamina to lamina are evident; nevertheless, no specific trend in internal architecture of the stromatolites was distinguished. EDS and X-ray data showed that the microbial laminae are constituted of low-Mg calcite crystals ranging in sizes from 5 to $30 \mu \mathrm{m}$ (Figs. 4, 5, 6a-b). Changes in the laminae composition are not evident, except for the stromatolites from the Yeseras Grandes where thin gypsum laminae were observed. Subhorizontal to cylindrical fenestrae, horizontal sheet-cracks (Fig. 3b) as well as polygonal cracks were observed. Fenestral voids are filled with small crystals of granular calcite. Small gastropods and coccolithophorids have been found among the laminae. Additionally, a relatively small proportion of quartz and feldspar grains has been observed.

Crinkle laminites (Fig. 3c) are composed of sheets of continuous to discontinuous small crinkles (Fig. 3d) pronounced by the alternation of dark submillimeter to millimeter micrite laminae up to $2 \mathrm{~mm}$ in thickness, with millimetric microsparitic laminae between 3 to $33 \mathrm{~mm}$ in thickness. These laminae have a heterogeneous fabric composed of cloudy microsparitic calcite crystals and irregular masses of homogenous micrite. Although at macroscopic scale the laminae exhibit an apparent lateral continuity, when observed under the microscope it becomes clear that the laminae are discontinuous showing frequent disruption of the lamina couplets (Fig. 3d). A complex internal microfabric has been observed, where evidence of erosion and irregularly distributed micritic rip-up intraclasts appear (Fig. 3f). Desiccation features of the crinkle laminate facies included micro-tepees, fenestrae, mud-cracks, and sheet-cracks. Tepees are very small, 10 to 20 $\mathrm{cm}$ in size. They appear commonly associated with a suite of features related to subaerial exposure.

\subsection{SEM and XRD analysis}

Extensive SEM examinations of polished and etched stromatolite samples were carried out. SEM observations revealed the presence of sub- $\mu \mathrm{m}$ scale filaments and nanoglobules in the studied samples. The size and shape of the microfossils are determined by bacterial morphology, which includes rodlike bacteria, and isolated subspherical structures. Rod-shape bacterium is sometimes called bacillus meanwhile the spherical to subspherical shapes are called coccoids.

The rod-like bacteria and shaped-like filaments consist of a dense meshwork of small irregular distributed filaments, which range from $150 \mathrm{~nm}$ and $640 \mathrm{~nm}$ in length. (Fig.5a-b) whereas diameters ranging from $54 \mathrm{~nm}$ and $105 \mathrm{~nm}$ show much smaller variability flattened ends and smooths surfaces. Although many rods occur isolated, sometime others show and incipient branching. Filaments appear straight or smoothly curved. In figure 5e, these filaments would seem to wrap micritic crystals. The result of the EDS analysis reveals that the mineralogical composition of the rod-like bacteria is mostly calcite as well as for the matrix (Fig. 5c-d).

Subspherical bodies (coccoid forms) range in size between 70 and $89 \mathrm{~nm}$ approximately (Fig.5f). These structures could represent the relicts of nanobacterial cells. The Oxfordian nanobacteria reported in this paper are comparable in size with published examples of nanobacteria bodies mentioned by Schrieber and Arnott (2003).

Scanning electron microscopy reveals that the stromatolites are micritic characterized by abundant subhedral crystals and measure from 2 and $4 \mu \mathrm{m}$ in size. However, the distribution of crystal grain sizes is heterogeneous and locally 

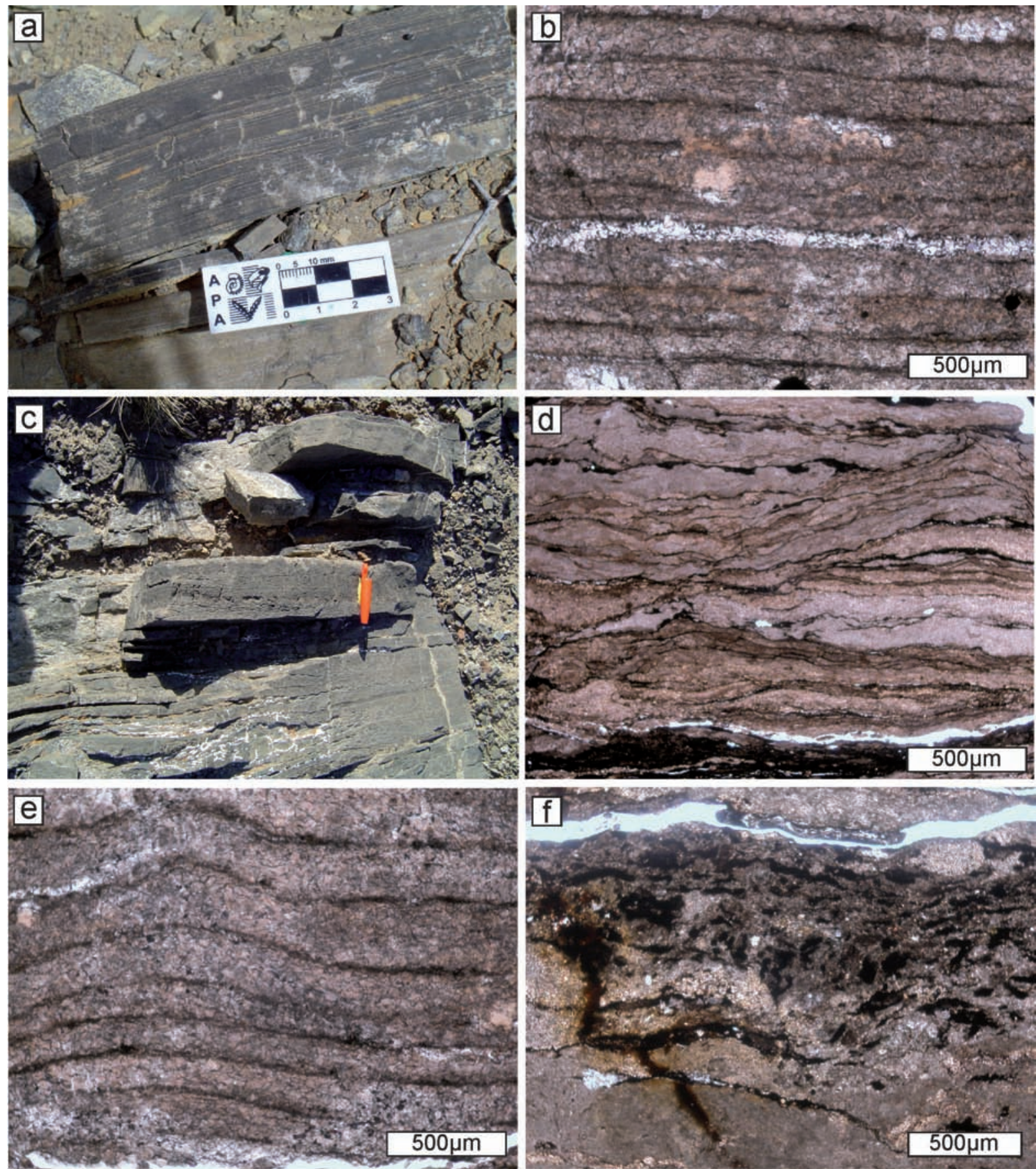

Fig. 3.- a) Field view of planar stromatolite; b) Thin section of planar stromatolite showing planar laminae composed of alternating microspar laminae and thin micrite laminae. Note fenestra vug and sheet-cracks; c) Field view of crinkle stromatolite. Note micro-tepee and mudcracks; d) Crinkle and discontinuous laminae composed of microsparitic and thin micrite laminae. Crinkle laminate showing irregular and interrupted lamination; e) Planar stromatolite composed of continuous microsparitic laminae and discontinuos thin micrite laminae. Note the presence of local increases in lamination convexity. Small dome are covered by upward flattering laminae; f) Crinkle laminae composed of alternating microsparitic laminae and thin micrite laminae. Note peloidal to dense micrite and small rip-up clasts.

microspar crystals $(>4 \mathrm{~mm})$ with dominant anhedral or subhedral crystals are also common. Among network rod-shaped nanobacteria is very common the presence of framboidal pyrite. Based on SEM observations of the micro-textures, disseminated spheroidal to sub-spheroidal aggregates, $4 \mu \mathrm{m}$ in diameter composed of individual euhedral crystallites of size less than 0.5 micron have been identified (Fig. 6c-e). EDS spectrum analyzes of these bodies are showing in figure $6 \mathrm{~d}-\mathrm{f}$.
Their presence seems to be a quite common feature in modern and ancient microbialites (Ezaki et al. 2008; Spadafora et al., 2010).

\subsection{Mineralogy}

Four microbialite samples were selected and prepared for X-ray diffraction (XRD) analysis (Fig. 4). In each one, three 

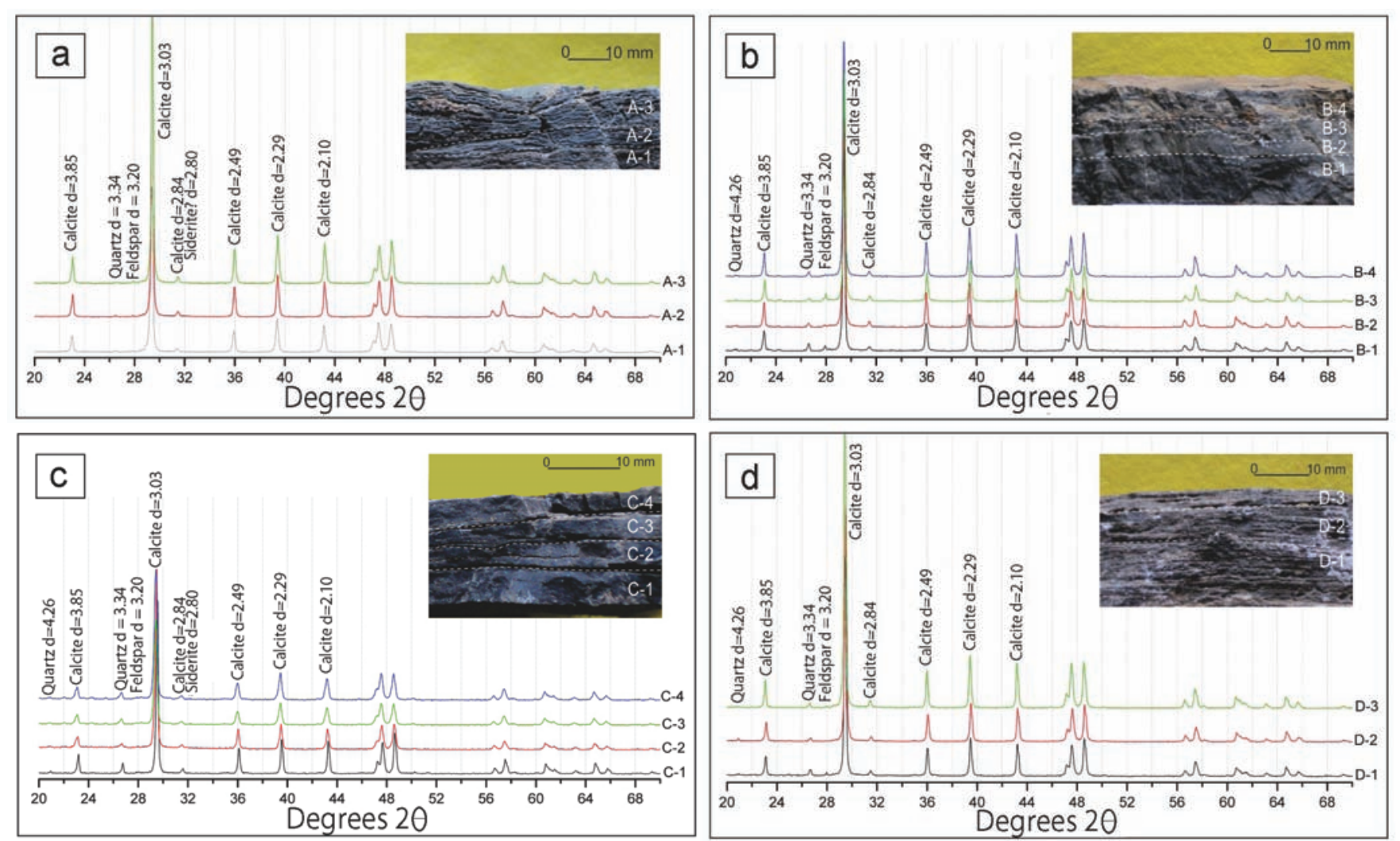

Fig. 4.- a,b,c,d) Results from X-ray diffraction analysis taken from stromatolite laminae.

to four sets of laminae were recognized, but a no substantial mineralogical variation between successive stromatolite laminae has been determined.

$\mathrm{X}$-ray diffraction analysis shows calcite as the predominant carbonate phase (up to $98.11 \%$ ). All samples contain detrital quartz and feldspar grains with percentages being low as $<1 \%$ to $5 \%$ and $<1 \%$ to $4.91 \%$ respectively. Detrital grains probably occur between or among stromatolitic laminae. Two samples show low percentages of siderite $(<1 \%)$. The origin of siderite may be considered authigenic. In fact, it may be originated in a variety of sedimentary environments (Huggett et al., 2000), but its formation in very shallow intertidal settings is related to large amounts of decaying organic matter and high bacterial activity, like sulphate reduction (Pye, 1984). XRD analysis demonstrates that all types of stromatolitic laminae have the same mineralogical composition (Table 1).

\section{Discussion}

Stromatolites are the result of a combination of processes that can include sediment trapping, binding, microbial calcification and carbonate precipitation induced by cyanobacteria and also associated bacteria (Riding, 2000). Microbial processes, such as photosynthesis, cyanobacterial calcification, and decomposition of organic matter, directly or indirectly influenced and controlled the carbonate precipitation by repeatedly accretive growth of microbial communities (Flügel, 2004; Kazmierczak et al., 2004).

In La Manga Formation, planar to crinkle stromatolites with continuous to discontinuous laminae are regarded as stromatolites in which microbial influences were dominant. Stromatolitic laminae, either planar or crinkle, show microscopic features such as micritic laminae, clotted to peloidal micrite and fenestrae which are similar to examples de-

\begin{tabular}{|c|c|c|c|c|c|c|c|c|c|c|c|c|c|c|}
\hline & \multicolumn{14}{|c|}{ Sample } \\
\hline & A-1 & A-2 & A-3 & B-1 & B-2 & B-3 & B-4 & $\mathrm{C}-1$ & C-2 & C-3 & C-4 & D-1 & D-2 & D-3 \\
\hline \multirow{2}{*}{ Calcite } & 98.54 & 98.39 & 98.21 & 93.98 & 97.41 & 97.45 & 94.21 & 94.99 & 96.89 & 93.83 & 94.62 & 95.92 & 98.82 & 98.91 \\
\hline & 0.38 & 0.54 & 0.48 & 0.35 & 0.33 & 0.35 & 0.34 & 0.34 & 0.48 & 0.71 & 0.32 & 0.36 & 0.35 & 0.41 \\
\hline Siderite & $<1$ & $<1$ & $<1$ & & & & & $<1$ & $<1$ & $<1$ & & & & \\
\hline \multirow{2}{*}{ Quartz } & \multirow{2}{*}{$<1$} & \multirow{2}{*}{$<1$} & \multirow{2}{*}{$<1$} & 2.37 & 1.22 & 1.37 & \multirow{2}{*}{$<1$} & 3.32 & \multirow{2}{*}{$\begin{array}{l}1.92 \\
0.04\end{array}$} & 2.70 & \multirow{2}{*}{$\begin{array}{l}5.38 \\
0.04\end{array}$} & 2.32 & \multirow{2}{*}{$\begin{array}{l}1.18 \\
0.03\end{array}$} & \multirow{2}{*}{$\begin{array}{l}1.09 \\
0.03\end{array}$} \\
\hline & & & & 0.03 & 0.03 & 0.03 & & 0.06 & & 0.05 & & 0.03 & & \\
\hline \multirow{2}{*}{ Feldspar } & \multirow{2}{*}{$<1$} & \multirow{2}{*}{$<1$} & 1.13 & 3.64 & 1.38 & 1.17 & 4.91 & 1.33 & \multirow{2}{*}{$<1$} & 3.19 & & 1.76 & & \\
\hline & & & 0.06 & 0.07 & 0.05 & 0.05 & 0.11 & 0.14 & & 0.18 & & 0.08 & & \\
\hline
\end{tabular}

The modal proportions, with standard errors, are quoted in $\mathrm{wt} \%$.

Table 1.- Results from X-ray diffraction analysis. Quantitative mineral-phase-analysis of study samples, based in the Rietvetd method. 

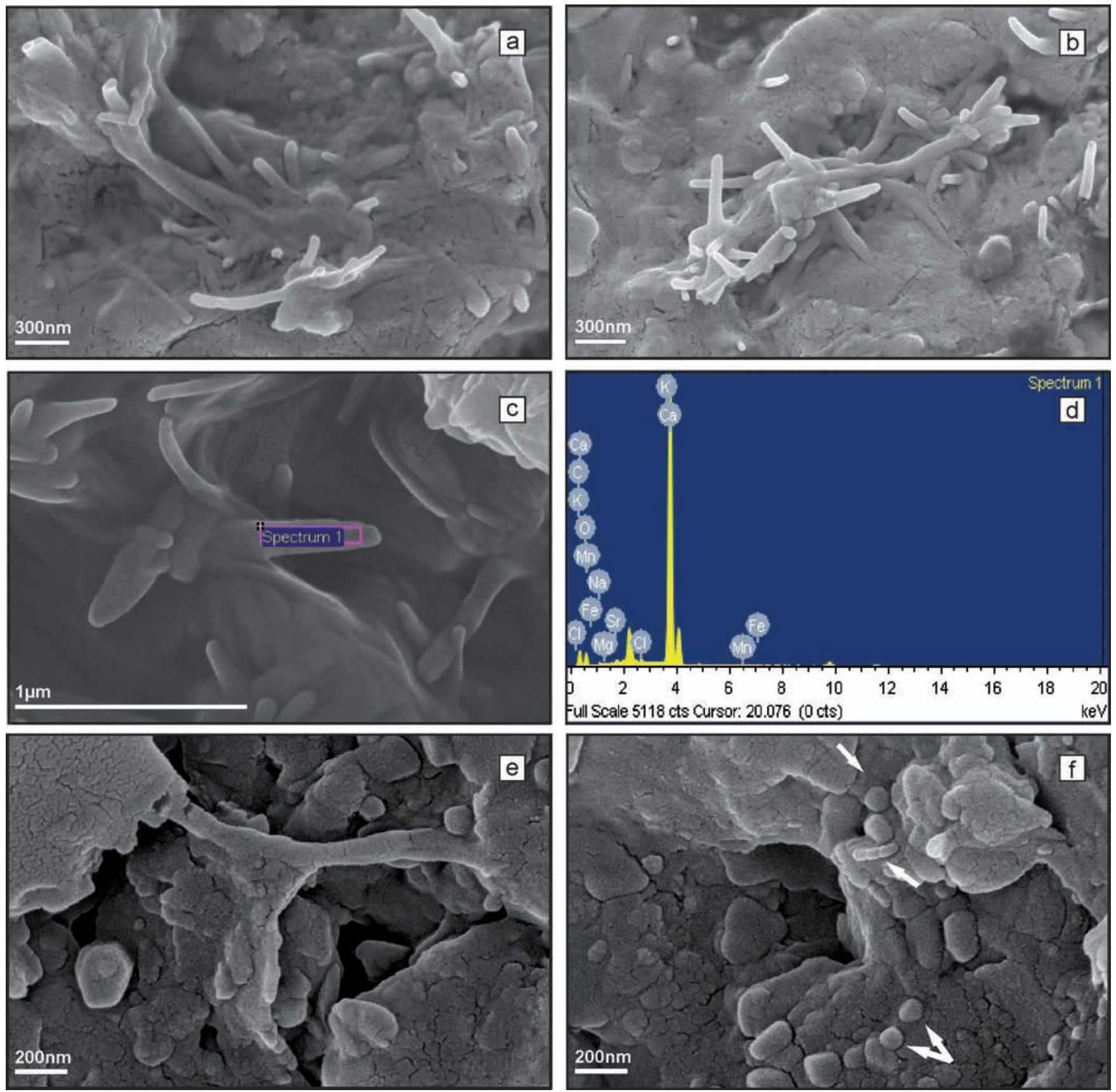

Fig. 5.- a,b) Scanning electron micrograph of dense meshwork of straight to slightly rod-like bacteria; c) Close view of rod-like bacteria. Note their smooth surface; d) EDS spectrum on filaments in figure 5c. Area in box was scanned for elements; f) Close view of small filaments between micrite crystals; f) Spheroidal bodies surrounded by micrite crystals and interpreted as nanobacteria.

scribed from Proterozoic and Early Phanerozoic nearshore settings (e.g., Pratt and James, 1982; Batten et al., 2004) to Recent in age (Friedman et al., 1985; Riding, 2000).

The lacking of significant changes in the thickness of laminae suggests that the influence of wave action or tidal currents regime was probably minimal, with the sediment input as limiting factor. The presence of convex-up laminae growing on planar or wavy laminae could be related to the sediment cohesion; nonetheless this kind of growth could be suggestive of changes in the style of calcification (Reid et al., 2000). Furthermore the frequent microspar laminae are related to recrystallized original micritic laminae.
Only at the Yeseras Grandes locality (Fig. 1a) stromatolites show alternations of submillimeter- to millimeter-thick beds of gypsum and calcite. This could be indicating more restricted conditions and active evaporation as well as different chemical conditions of the water caused by salinity fluctuations in the upper intertidal to supratidal setting. Similar facies have been previously described in modern microbial mats in the coastal sabkha at Abu Dhabi, United Arab Emirates (Handford et al., 1982).

Planar and crinkle laminations are often vertical- and horizontally disrupted by subaereal exposition processes (sheetcracks, mud-cracks, and fenestral pores). The crinkle irregu- 

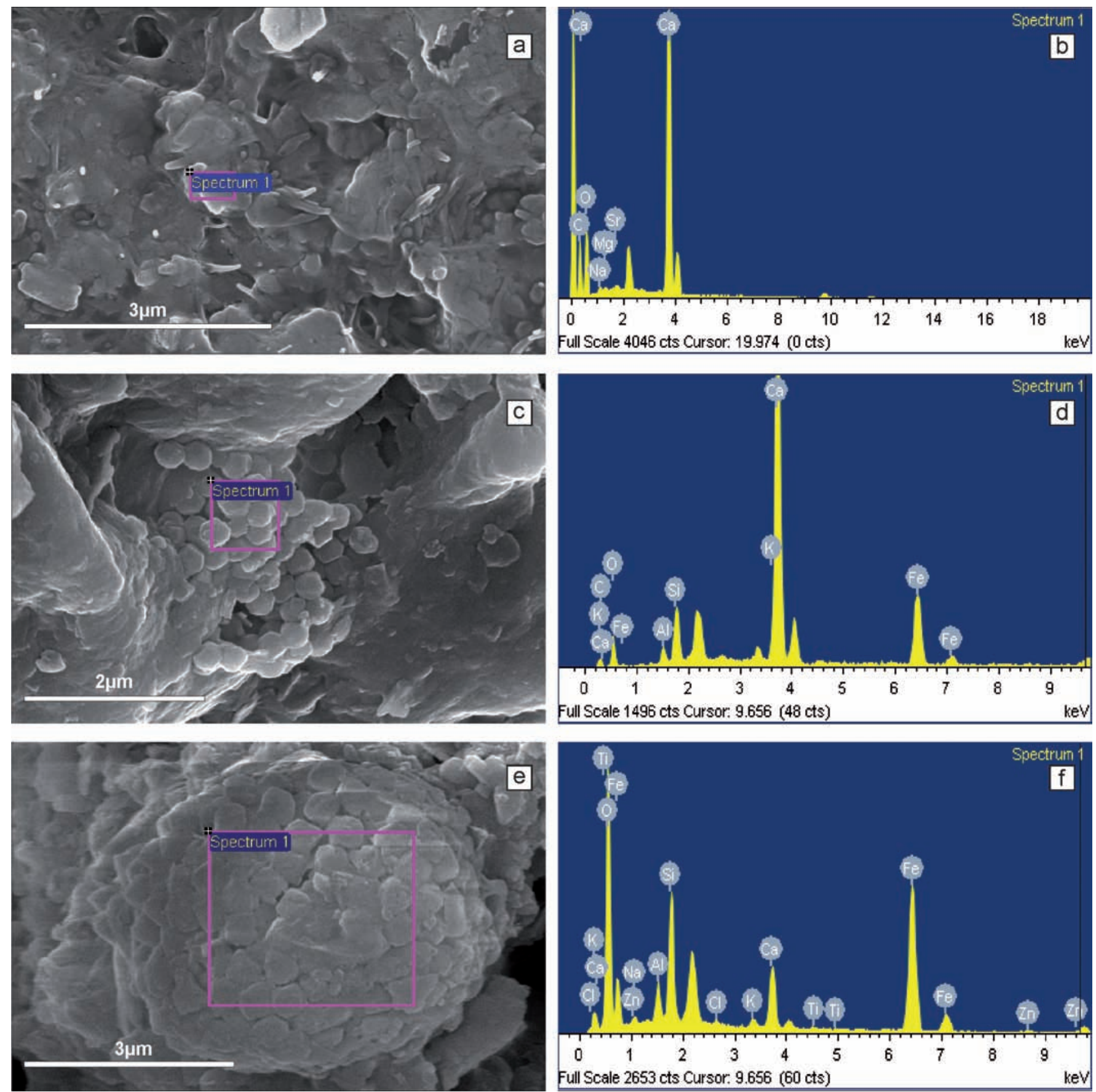

Fig. 6.- a) Representative scanning electron photomicrograph of micrite crystals. Note the presence of rod-like bacteria; b) EDS spectrum analysis of micrite crystals in figure 6a; c) Scanning electron photomicrograph of a typical framboidal pyrite found with rod-like bacteria; d) EDS spectrum of framboid. Area in box was scanned for elements; e) Pyrite framboid cluster showing spheroidal assemblage of submicron-size crystals of pyrite; f) EDS spectrum of submicron-size crystals of pyrite area in box (Fig. 6e) was scanned for elements.

lar surfaces on top of the stromatolites beds were interpreted as redeposited fragments of desiccated mats (e.g. Schieber, 1998).

The origin of fenestrae is attributed to dessication and shrinkage as well as to gas bubbles, which were produced by the degradation of organic matter. The abundance of fenestral structures suggests a shallow water realm ranging from intertidal to supratidal depositional facies (e.g. Beukes, 1987; Altermann, 2008). The cavities are filled with sparry calcite, which is attributed to early diagenesis (Flügel, 2004).

According to Riding (2000), the clotted to peloidal microfabrics in stromatolite beds are typical of microbial carbonates in which sulphate reducing bacteria degrade organic matter within the microbial mats, promoting calcification (Riding and Tomás, 2006). These processes may have built stromatolites since the Early Archean (Hofmann, 2000; Schopf, 2006). 
Peloids, frequent within the stromatolitic laminae, are irregularly spherical. Chafetz (1986) and Riding (2002) proposed that peloids could be attributed to calcified bacteria. It has been reported that $\mathrm{CaCO}_{3}$ precipitation takes place as a result of degradation of organic matter by heterotrophic bacteria, which plays a significant role in the lithification process of microbial mats (Riding and Tomás, 2006).

Studies made on modern microbial mats suggest that the formation of peloidal carbonate precipitates is associated with bacterial metabolic activities (Dupraz et al., 2004). Nonetheless, the peloidal microfabrics can be formed in situ during very early diagenesis, closely linked with the degradation and calcification of organic matter (EPS) driven by heterotrophic bacteria, mainly sulfate-reducing bacteria (Riding and Tomás, 2006; Dupraz et al., 2009). Actually, from a sedimentological point of view, cyanobacteria are particularly important because of their ability to precipitate minerals and also for trapping and binding existing sediments. On the other hand, cyanobacteria can also be regarded as almost exclusively responsible for the micritization of carbonate grains in shallow tropical seas (Golubic et al., 2000). Actually, micritization of allochems particles is a common feature in the $\mathrm{La}$ Manga Formation.

The origin of the flat-pebble conglomerates (FPB) facies is related to rework from lithified or partially lithified microbial mats and re-deposition by storms during the marine flooding on top of the microbial laminated facies. In fact, the high profusion of FPC levels is a direct expression of the frequency of storm events (Palma et al., 2013).

Although storm activity probably fluctuated significantly (eventually becoming enhanced), the microbial communities recovered soon after the storm had ceased. In fact, planar to crinkle stromatolites evidence the trapping by microbial mats of fine scarce grained sediments settled down from the water after a storm in upper intertidal to lower supratidal environments. The uncommon detrital materials suggest that stromatolites may have formed mostly by in situ precipitation of carbonate rather than by trapping and bidding the sediments (cf. Riding, 1999). Studies in recent stromatolites show that planar to crinkle microbial mats grow frequently above mean low water level or tidal flats that are periodically flooded and exposed (Reid et al., 2011).The presence of abundant ammonites such as Mirosphynctes sp., regular echinoids and reworked intraclasts on the top of stromatolite beds is straight evidence of storm action (Palma et al., 2012, 2013) as well as the presence of coccolithophorids within the microbial laminae.

The remarkable preservation of nanobacteria in the stromatolites from the peritidal deposits from the La Manga Fm. suggests that diagenesis did not destroy any rod-like bacteria, so that they probably maintained their primary carbonate mineralogy. This is extremely surprising because stromatolites from peritidal settings are usually very prone to dolomitization (Mancini and Parcell, 2001). In the case herein presented, rod-like bacteria were not affected by dolomitization.
Studies carried out by Visscher et al. (2005) show that modern stromatolites from the Bahamas Islands are the result of different microbial communities. Although cyanobacteria are always associated to stromatolites, they are not the only microbes. Recent studies in stromatolites from Shark Bay, Australia, show that diversity is represented mainly by bacteria and archeas (Burns et al., 2004). The co-existence of rod-like bacteria and nanobacteria has been recognized in modern stromatolites from Exuma Island, Bahamas by Reid et al. (2011).

Astonishingly, putative nanobacteria observed in the stromatolites from the La Manga Fm. exhibit rod-like or filamentous morphology contrasting with the usually described spheroidal morphology of nanobacteria (e.g. Folk, 1993; Folk and Chafetz, 2000). Nanometer-scale objects (20-200 nm wide) were described as "nanobacteria" by Folk (1993). These are basically objects found in sedimentary rocks that have typical morphology of bacteria by much smaller size, usually an order of magnitude below typical bacteria, as suggested by Schieber and Arnott (2003). The existence of nanobacteria has been challenged by the geological and microbiological communities because it has been difficult to extract genetic material due to their microscopic size. Nevertheless, Berner (1998) suggested that "if microorganisms use a catalytic biopolymer instead of a genetic biopolymer in the construction of cell walls, it may be possible to obtain smaller structures".

Modern bacteria $(1-2 \mu \mathrm{m})$ display morphologies ranging from spherical (coccoid), rod-shaped (bacillus), curved (vibriod), to spiral (spirochete or spirilli). Those of certain biogenicity have filamentous or rod-shaped morphology have been described from the Early Archean (Brock and Madigan, 1991). Extremes include nanobacteria which can be as small as 0.1-0.2 $\mu \mathrm{m}$ (Brock and Madigan, 1991). Of all the above mentioned morphologies, the rod- and worm-like calcified bacterial cells are those which may best serve to identify bacterially induced carbonate precipitation (Castanier et al., 1999; Warren et al., 2001).

The mineralogical and environmental implications of bacterially induced carbonate precipitation have been mentioned by several authors such as Folk (1993), Vasconcelos et al. (1995), Riding (2000), and Braissant et al. (2003, and references therein). Nanobacteria take place in different environments ranging from rocks to present-day sediments and living organisms, where they play a key role in precipitation in bacteria (e.g. Bontognali et al., 2008). In addition, nanoform microorganisms have been observed in modern natural environments as well as in laboratory culture experiments (van Lith et al., 2013). They have been considered as extremely small bacteria by Pacton and Gorin (2011).

Kazmierczak et al. $(1996,2004)$ and Dupraz et al. (2004) studied fossil and modern cyanobacterial mats finding similar coccoid shapes which they were interpreted as result of the selective degradation and mineralization of an organic EPS matrix. Riding (2000) suggested that in spite of bacterial type (autotrophic or heterotrophic; marine or non-marine), most 
morphologies of carbonates formed in the presence of bacteria are distinctive and could offer insights into this biomineralization process.

Experiments carried out by Schieber and Arnott (2003) showed spheroidal objects analogous to the nanobacteria size range (minor $50 \mathrm{~nm}$ ). These structures could be considered as product of decay and mineralization of organic tissues (e.g. Kirkland et al., 1999; Schieber and Arnott, 2003; Perri and Tucker, 2007). A biological origin is proposed for spherulitic structures for the Mesoproterozoic Gaoyuzhuang Fm., China (1.4-1.5 Ga) (Lee and Golubic, 1999).

There are many reports on the presence of nanometer-scale spheroids, 30-150 nm wide, which appear associated with organic debris in samples from the Holocene Tunisian microbial mat, and the Miocene Monterey Formation (California, USA) (in Pacton et al., 2010). Likewise Fratesi et al. (2004) recognized aggregations of bacteria together with microspheres (nanobacteria) in samples associated with biofilms from the Carter Sandstone of Alabama USA.

Schopf et al. (1965) have mentioned the presence of wellpreserved rod-shaped and coccoid bacteria in the cherts of the Precambrian Gunflint Iron Formation ( $1.9 \times 10^{9}$ years old $)$ and consider that these organisms are morphologically comparable to certain modern iron bacteria. In fact, new research carried out by Sánchez-Román et al. (2014) demonstrated the presence of rod-shaped bacteria embedded in the surface of siderite nanocrystals in samples from Rio Tinto (Spain). They suggest that precipitation of carbonates could be related to the microbial reduction of ferric iron coupled with the oxidation of organic compounds.

In order to explore their potential role in degradation and preservation of organic matter $(\mathrm{OM})$ in rocks, Pacton et al. (2010) have investigated the presence of microbial recent activity and in the fossil record showing nanometer-scale spheroids with extracellular polymeric substances (EPS) and bacterial cell walls.

Numerous articles have addressed to the problem of the microbial diversity and their mineralogy and the role of some microorganisms on mineral precipitation (Reid et al., 2000; López García et al., 2005). In our case, we suggest that intertidal to supratidal settings could have been supersaturated with carbonates minerals so that accretion, lamination and lithification of stromatolites occurred, similarly to the process occurring in modern stromatolites (Reid et al., 2000). Peritidal environments from the La Manga Formation were affected by regular seawater inundation and subaerial exposure (including episodic dessication) and episodic storm influences (Palma et al., 2013).

Microbes, including cyanobacteria, fungi, microalgae and others have a significant influence on stromatolite formation (Nealson, 1997; Riding, 2000; Riding and Awramik, 2000) which together contribute to the biostabilization of the sedimentary peritidal areas. Although photosynthesis facilitates the precipitation of calcium carbonates such as aragonite (Dupraz and Visscher, 2005; Kremer et al., 2008), decom- position of cyanobacterial extracelular organic matter by microheterotrophs could also participate in the precipitation of calcium carbonate (Paerl et al., 2001). It is noteworthy that during SEM observations of the analyzed samples of the La Manga Fm., the presence of cyanobacteria was not observed, which could probably be related to decaying colonies by bacterial activity and physicochemical degradation as suggested Dupraz and Visscher (2005) and Braissant et al. (2007).

The occurrence of framboidal pyrites is often related to the metabolic activity of sulfate-reducing bacteria and the decay of organic matter. In fact, some authors consider the presence of framboidal pyrite as an indicator of the involvement of sulfate-reducing bacteria in the precipitation of the microbialites (Westphal et al., 2010). The formation of pyrite framboids in sediments requires an anaerobic environment, either within the sediment or inside a local microenvironment. It is worth mentioning that sulfate reduction occurs in Bahamian stromatolites in an anoxic layer several millimeters below the photosynthetic zone (Visscher et al., 1998). Isolated framboidal aggregates of pyrite also indicate microbial activity meanwhile framboidal shape is also considered a morphological biomarker (Popa et al., 2004). Likewise, Raiswell et al. (1993) and Taylor and Macquarker (2000) suggested that framboidal pyrites formed during early diagenesis from ironrich porewaters at sites of sulfide presence (i.e., near organic matter, due to bacterial sulfate reduction).

\section{Conclusions}

Oxfordian stromatolites from the La Manga Fm have planar and crinkle forms with internally similar textures. The laminations are interpreted as the periodical response of the microbial community to the microbial growth and its surrounded environment. Extensive SEM examinations show a network of rod-shaped nanobacteria and small subspherical aggregates that strongly resemble coccoid bacteria. Because of their abundance, they probably play a critical role in the precipitation of carbonate minerals. The Oxfordian stromatolites from the La Manga Formation can be consider as biologically induced formations, where chemical variations ( $\mathrm{pH}$, alkalinity) and metabolic activity induced by microbes or sulphate-reducing bacteria could have increased the alkalinity and stimulate carbonate precipitation.

\section{Acknowledgments}

This research was supported by Consejo Nacional de Investigaciones Cientificas (CONICET) PIP-0546, and by FONCYT (2012-2542). We are grateful to Dr. Maria Claudia Marchi for help during the work with the SEM microscope and the EDS system (CMA, Centro de Microscopias Avanzadas, Facultad de Ciencias Exactas y Naturales, Universidad de Buenos Aires). The authors also thank A. Riccardi and A. Concheyro for paleontological determinations. We tank to G. Herrero (Universidad Complutense, Madrid, Spain) for his 
help with the preparation of the samples and J.C. Poblete for his assistance in the field. Thanks to A. Gandolfo for helpful comments on earlier versions of the manuscript. Coments of anonymous reviewers are kindly acknowledged. This is the contribution R-182 of the Instituto de Estudios Andinos Don Pablo Groeber (IDEAN).

\section{References}

Altermann, W. (2008): Accretion, trapping and binding of sediment in Archean stromatolites morphological expression of the antiquity of life. Space Science Review 135, 55-79. doi: 10.1007/978-0-38777516-6 7.

Batten, K.L., Narbonne, G.M., James, N.P, (2004): Paleoenvironments and growth of early Neoproterozoic calcimicrobial reefs: platformal Little Dal Group, northwestern Canada: Precambrian Research 133, 249-269. doi:10.1016/j.precamres.2004.05.003.

Benner, S.A. (1998): How small can microorganism be? Workshop on Size Limits of Very Small Microorganisms. Natural Research Council. Washington DC, pp. 22-23.

Beukes, N.J. (1987): Facies relations, depositional environments and diagenesis in a major early Proterozoic stromatolitic carbonate platform to basinal sequence, Campbellrand Subgroup, Transvaal Supergroup, South Africa. Sedimentary Geology 54, 1-46. doi:10.1016/00370738(87)90002-9.

Bontognali, T.R.R., Vasconcelos, C., Warthmann, R.J., Dupraz, Ch., Bernasconi, S.M., Mckenzie, J.A. (2008): Microbes produce nanobacteria-like structures, avoiding cell entombment. Geology 36(8), 663-666. doi: 10.1130/G24755A.1.

Braissant, O., Cailleau, G., Dupraz, C., Verrecchia, E.P. (2003): Bacterially induced mineralization of calcium carbonate in terrestrial environments: the role of exopolysaccharides and amino acids. Journal of Sedimentary Research 73, 485-490. doi: 10.1306/111302730485.

Braissant, O., Decho, A.W., Dupraz, C., Glunk, C., Przekop, K.M., Visscher, P.T. (2007): Exopolymeric substances of sulphate-reducing bacteria: interactions with calcium at alkaline $\mathrm{pH}$ and implications for formation of carbonate minerals. Geobiology 5, 401-411. doi: 10.1111/j.1472-4669.2007.00117.x.

Brock, T.D., Madigan M.T. (1991): Biology of Microorganisms, Prentice-Hall, 874 pp.

Burns, B.P., Goh, F., Allen, M., Brett, A.N. (2004): Microbial diversity of extant stromatolites in the hypersaline marine environment of Shark Bay, Australia. Environmental Microbiology 6, 1096-1101. doi: 10.1111/j.1462-2920.2004.00651.x.

Camoin, G., Gautret, P., Montaggioni, L.F., Cabioch, G. (1999): Nature and environmental significance of microbialites in Quaternary reefs: the Tahiti paradox. Sedimentary Geology 126, 271-304. doi: 10.1016/ S0037-0738(99)00045-7.

Castanier, S., Le Metayer-Levrel, G., Perthuisot, J.P. (1999): Ca-carbonates precipitation and limestone genesis-the microbiologist point of view. Sedimentary Geology 126, 9-23. doi: 10.1016/S00370738(99)00028-7.

Clarke, W., Konhauser, K.O., Thomas, J., Bottrel, S.H. (1997): Ferric hydroxide and ferric hydroxysulphate precipitation by bacteria in an acid drainage lagoon. FEMS Microbiology Reviews, 20, 351-361. doi: 10.1111/j.1574-6976.1997.tb00320.x.

Chafetz, H.S. (1986): Marine peloids: A product of bacterially induced precipitation of calcite. Journal Sedimentary Petrology 56, 812817. doi: 10.1306/212F8A58-2B24-11D7-8648000102C1865D.

Dupraz, C., Reid, R.P., Braissant, O., Decho, A.W., Norman, R.S., Visscher, P.T. (2009): Processes of carbonate precipitation in modern microbial mats. Earth-Science Reviews 96, 141-162. doi:10.1016/j. earscirev.2008.10.005

Dupraz, C., Visscher, P.T. (2005): Microbial lithification in marine stromatolites and hypersaline mats. Trends in Microbiology 13, 429-438. doi:10.1016/j.tim.2005.07.008.

Dupraz, C., Visscher, P.T., Baumgartner, L.K, Reid, R.P. (2004): Microbe-mineral interactions: early $\mathrm{CaCO} 3$ precipitation in a Recent hypersaline lake (Eleuthera Islands, Bahamas). Sedimentology 51, 745-765. doi: 10.1111/j.1365-3091.2004.00649.x.

Ezaki, Y., Liu, J., Nagano, T., Adachi, N. (2008): Geobiological aspects of the Earliest Triassic microbialites along the southern periphery of the tropical Yangtze Platform: Initiation and cessation of a microbial regime. Palaios 23, 356-369. doi: 10.2110/palo.2007.p07-035r.

Folk, R.L. (1993): SEM imaging of bacteria and nannobacteria in carbonate sediments and rocks. Journal of Sedimentary Petrology 63, 990-999. doi: 10.1306/D4267C67-2B26-11D7-8648000102C1865D.

Folk, R.L. (1999): Nannobacteria and the precipitation of carbonate in unusual environments, Sedimentary Geology 126, 47-55. doi:10.1016/S0037-0738(99)00031-7 .

Folk, R.L., Chafetz, H.S.(2000): Bacterially induced microscale and nanoscale carbonate precipitates: In: Riding, R., and Awramik, S.M. (eds.), Microbial Sediments, Springer, pp. 40-49. doi: 10.1007/978-3662-04036-2_6.

Flügel, E. (2004): Microfacies of carbonate rocks-analysis, interpretation and application. Springer, pp. 190-203. doi: 10.1007/978-3-66208726-8.

Franke, R.B., Bazylinsky, D.A. (2003): Biologically induced mineralization bacteria. In: Dove, P.M., Weiner, S., De Yoreo, J.J. (eds.), Biomineralization. Mineralogical Society of America. Review in Mineralogy and Geochemistry 54, 95-114.

Fratesi, S.E., Lynch, F.L., Kirkland, B.L, Brown, L.R. (2004): Effects of SEM preparation techniques on the appearance of bacteria and biofilms in the Carter Sandstone. Journal of Sedimentary Research 74, 858-867. doi: 10.1306/042604740858.

Friedmann, G.M., Sneh, A., Owen, R.W. (1985): The Ras Muhammad Pool: Implications for the Gavish Sabkha. In: Friedmann, G.M., Krumbein, W.E. (eds.), Hypersaline Ecosystems, The Gavish Sabkha, Ecological Studies 53. Springer, pp. 218-237. doi: 10.1007/978-3642-70290-7 13.

Giambiagi, L., Bechis, F., Lanés, S., Tunik, M., García, V., Suriano, J., Mescua, J. (2008): Formación y evolución Triásico-Jurásica del depocentro Atuel, Cuenca Neuquina, provincia de Mendoza. Revista de la Asociación Geológica Argentina 63, 520-533.

Golubic, S., Seong-Joo, L., Browne, K.M. (2000): Cyanobacteria: architects of sedimentary structures, in Riding, R.E., and Awramik, S.M. (eds.), Microbial Sediments, Springer, pp. 57-67. doi: 10.1007/978-3662-04036-2_8.

Handford, R., Loucks, R.G., Davies, G.R. (1982): Depositional and diagenesis spectra of evaporates. Society of Economic Paleontologists and Mineralogists, Core Workshop 3, pp. 395.

Hofmann, H.J., Pearson, D.A.B., Wilson, B.H. (1980): Stromatolites and fenestral fabric in Early Proterozoic Huronian Supergroup, Ontario. Canadian Journal of Earth Sciences 17, 1351-1357. doi: 10.1139/ e80-142.

Hofmann, H. J. (2000): Archean stromatolites as microbial archives. In: Riding, R.E., Awramik, S. M. (eds.), Microbial Sediments. Springer, pp. 315-327. doi: 10.1007/978-3-662-04036-2_34.

Huggett, J., Dennis, P., Gale, A. (2000): Geochemistry of early siderite cements from the Eocene succession of Whitecliff Bay, Hampshire Basin, U.K. Journal of Sedimentary Research 70, 1107- 1117. doi: 10.1306/112399701107.

Ishikawa M., Ichikuni, M. (1984): Uptake of sodium and potassium by calcite. Chemical Geology 42, 137-146. doi:10.1016/00092541(84)90010-X. 
Kazmierczak, J., Coleman, M., Gruszczynski, M., Kempe, S. (1996): Cyanobacterial key to the genesis of micritic and peloidal limestones in ancient seas. Acta Palaeontologica Polonica 41, 319-338.

Kazmierczak, J., Kempe, S. (2004): Microbialite Formation in Seawater of Increased Alkalinity, Satonda Crater Lake, Indonesia: Discussion. Journal of Sedimentary Research 74, 314-317. doi: 10.1306/061303740314.

Kazmierczak, J., Kempe, S., Altermann, W. (2004): Microbial origin of Precambrian carbonates: Lessons from modern analogues. In: Eriksson, P.G., Altermann, W., Nelson, D.R., Mueller, W., Catuneanu, O. (eds.), The Precambrian Earth: Tempos and Events. Developments in Precambrian Geology, Elsevier, pp. 545-563.

Kirkland, B.L., Lynch, F.L., Rahnis, M.A., Folk, R.L., Molineux, I.J., Mclean, R.J.C. (1999): Alternative origins for nannobacteria-like objects in calcite. Geology 27, 347-350. doi: 10.1130/0091-7613(1999) $027<0347$ :AOFNLO $>2.3$.CO;2.

Knorre, H., Krumbein, W.E. (2000): Bacterial calcification, In: Riding, R.E., Awramik, S.M., (eds.), Microbial Sediments. Springer, pp. 2531. doi: 10.1007/978-3-662-04036-2 4.

Konhauser, K.O. (1998): Diversity of bacterial iron mineralization. Earth Science Reviews 43, 91-121. doi:10.1016/S0012-8252(97)00036-6.

Kremer, B., Kazmierczak, J., Stal, L.J. (2008): Calcium carbonate precipitation in cyanobacterial mats from sandy tidal flats of the North Sea. Geobiology 6, 46-56. doi: 10.1111/j.1472-4669.2007.00128.x.

Lee, D.J., Golubic, S. (1999): Microfossil population in the context of synsedimentary micrite deposition and acicular carbonate precipitation: Mesoproterozoic Gaoyuzhang Formation, China. Precambrian Research 96, 183-208. doi: 10.1016/S0301-9268(99)00004-2.

Legarreta, L., Gulisano, C. A. (1989): Análisis estratigráfico secuencial de la Cuenca Neuquina (Triásico Superior- Terciario Inferior), Argentina. In: Chebli, G.A., Spalletti, L.A. (eds.), Cuencas Sedimentarias Argentinas, Simposio Cuencas Sedimentarias Argentinas, Serie Correlación Geológica 6, 221-243.

López-García, P., Kazmierczak, J., Benzerara, K., Kempre, S., Guyot, F., Moreira, D. (2005): Bacterial diversity and carbonate precipitation in the giant microbialites from the highly alkaline Lake Van, Turkey. Extremophiles 9, 263-274. doi: 10.1007/s00792-005-0457-0.

Madigan, M.T., Martinko, J.M. (2006): Brock Biology of Microorganisms, Pearson Prentice Hall, pp. 992.

Mancini, E. A., Parcell, W. C. (2001): Outcrop analogs for reservoir characterization and modeling of Smackover microbial reefs in the northeastern Gulf of Mexico area. Gulf Coast Association of Geological Societies Transactions 51, 207-218.

Mitchum, R. M. JR., Uliana M. A. (1985): Seismic stratigraphy of carbonate depositional sequences, Upper Jurassic-Lower Cretaceous. Neuquén Basin, Argentina. In: Berg, R.B., Woolverton, D.G. (eds.), Seismic Stratigraphy: an integrated Approach to Hydrocarbon Exploration. American Association of Petroleum Geologists, Memoir 39, 255-274.

Nealson, K. (1999): Discussion. In Steering Group (eds.), Size limits of very small microorganisms: proceedings of a workshop: National Academy Press, National Research Council, Space Studies Board, 39-42.

Pacton, M., Gorin, G. G. (2011): Nan(n)obacteria. In: Reitner, J., Thiel, V. (eds.), Encyclopedia of Geobiology. Springer, 677-680. doi: 10.1007/978-1-4020-9212-1_154.

Pacton, M., Gorin, G., Vasconcelos, C., Gautschi, H.P., Barbarand, J. (2010): Structural arrangement of sedimentary organic matter: nanometer-scale spheroids as evidence of a microbial signature in early diagenetic processes. Journal of Sedimentary Research 80, 919-932. doi: 10.2110/jsr.2010.082.

Paerl, H.W., Steppe, T.F., Reid, R.P. (2001): Bacterially mediated precipitation in marine stromatolites. Environmental Microbiology 3, 123-130. doi: 10.1046/j.1462-2920.2001.00168.x.
Palma, R. M., Kietzmann D. A., Adamonis, S., López-Gómez, J. (2009): Oxfordian reef architecture of the La Manga Formation, Neuquén Basin, Mendoza Province, Argentina. Sedimentary Geology 221, 127-140. doi:10.1016/j.sedgeo.2009.09.004.

Palma, R. M., Kietzmann D. A., Martín-Chivelet, J., López-Gómez J., Bressan G. S. (2010): Lower Callovian-Middle Oxfordian facies from the La Manga Formation carbonate ramp: a forced regression. Atuel Depocenter, Neuquén Basin, Mendoza Province, Argentina. The $8^{\text {th }}$ International Congress on the Jurassic System, Sichuan, China. Earth Science Frontiers 17, 302-203.

Palma, R. M., Kietzmann, D. A., Martín-Chivelet, J., López-Gómez J., Bressan, G.S. (2012): New biostratigraphic data from the CallovianOxfordian La Manga Formation, Neuquén Basin, Argentina: Evidence from an ammonite condensed level. Revue de Paléobiologie, Genève, Vol. spéc.11, 345-356.

Palma, R. M., Kietzmann, D. A., Bressan, G. S., Martín-Chivelet, J., López-Gómez J, Farias, M.E., Iglesias Llanos, M.P. (2013): Peritidal cyclic sedimentation from La Manga Formation (Callovian-Oxfordian) Neuquén Basin, Mendoza, Argentina. Journal of South American Earth Sciences 47, 1-11. doi:10.1016/j.jsames.2013.05.008.

Palma R. M., López-Gómez J., Piethé, R. D. (2007): Oxfordian ramp system (La Manga Formation) in the Bardas Blancas area (Mendoza Province), Neuquén Basin, Argentina: facies and depositional sequences. Sedimentary Geology 195, 113-134. doi:10.1016/j.sedgeo.2006.07.001.

Papineau, D., Walker, J.J., Mojzsis, S.J., Pace, N.R. (2005): Composition and Structure of Microbial Communities from Stromatolites of Hamelin Pool in Shark Bay, Western Australia. Applied and Environmental Microbiology 71, 4822-4832. doi: 10.1128/AEM.71.8.48224832.2005.

Perri, E., Tucker, M. (2007): Bacterial fossils and microbial dolomite in Triassic stromatolites. Geology 35:207-210. doi: 10.1130/G23354A.1.

Popa, R., Kinkle, B.K., Badescu, A. (2004): Pyrite framboids as biomarkers for iron-sulfur system. Geomicrobiology Journal. 21, 193-206. doi: 10.1080/01490450490275497.

Pratt, B.R., James, N.P. (1982): Cryptalgal-metazoan bioherms of early Ordovician age in the St. George Group, western Newfoundland. Sedimentology 29, 543-569. doi: 10.1111/j.1365-3091.1982.tb01733.x .

Pye, K. (1984): SEM analysis of siderite cements in intertidal marsh sediments, Norfolk, England. Marine Geology 56:1-12. doi:10.1016/0025-3227(84)90002-1.

Raiswell, R., Whaler, K., Dean, S., Coleman, M.L., Briggs, D.E.G. (1993): A simple three-dimensional model of diffusion-with-precipitation applied to localized pyrite formation in framboids, fossils and detrital iron minerals. Marine Geology 113, 89-100. doi:10.1016/00253227(93)90151-K

Reid, P., Foster, J.S., Radtke, G., Golubic, R. (2011): Modern Marine Stromatolites of Little DarbyIsland, Exuma Archipelago, Bahamas: Environmental Setting, Accretion Mechanisms and Role of Euendoliths. In: Reitner, J., Quéric, N., Arp, G. (eds.), Advances in Stromatolites Geobiology 77-90. doi: 10.1007/978-3-642-10415-2_4.

Reid, R.P., James, N.P., Macintyre, I.G., Dupraz, C.P., Burne, R.V. (2003): Shark bay stromatolites: microfabrics and reinterpretationof origins. Facies 49, 299-324. doi: 10.1007/s10347-003-0036-8.

Reid, R.P., Gaspar, A.P., Bowlin, E.M., Custals, L., Andres, M.S. (2011): Microbialites and sediments: a two year record of burial and exposure of stromatolites and thrombolites at Highborne Cays, Bahamas. In: Seckbach, J., Tewari, V. (eds.), Stromatolites-Interaction of Microbes with Sediments, Springer. pp. 407-425. doi: 10.1007/978-94-0070397-1 18.

Reid., R.P., Visscher, P.T., Decho, A.W., Stolz, J.F., Bebout, B.M., Dupraz, C., Macintyre, I.G., Paerl, H.W., Pinckney, J.L., Prufert-Bebout, L., Steppe, T.F., DesMarais, D.J. (2000): The role of microbes in accretion, lamination and early lithification of modern marine stromato- 
lites. Nature 406, 989-992. doi: 10.1038/35023158.

Riding, R. (2000): Microbial carbonates; the geological record of calcified bacterial-algal mats and biofilms. Sedimentology 47 (Suppl.1), 179-214. doi: 10.1046/j.1365-3091.2000.00003.x.

Riding, R. (2002): Structure and composition of organic reefs and carbonate mud mounds: concepts and categories. Earth-Science Reviews 58, 163-231. doi:10.1016/S0012-8252(01)00089-7.

Riding, R., Tomás, S. (2006): Stromatolite reef crusts. Early Cretaceous, Spain: bacterial origin of in situ- precipitated peloid microspar? Sedimentology 53, 23-34. doi: 10.1111/j.1365-3091.2005.00751.x.

Rietveld, H.M. (1969): A profile refinement method for nuclear and magnetic structures. Journal of. Applied. Crystallography 2, 65-71. doi: $10.1107 / \mathrm{S} 0021889869006558$.

Rodríguez Carvajal, J. (2001): Recent development of the Program FULLPROF. Commission on Powder Diffraction (IUCr), Newsletter 26, 12-19. .

Sánchez-Román, M., Fernández-Remolar, D., Amils, R., Sánchez-Navaz, A, Schmid, T, San Martín-Uriz, P., Rodríguez, N., McKenzie J.A., Vasconcelos, C. (2014): Microbial mediated formation of Fecarbonate minerals under extreme acidic conditions. Scientific Reports 4:4767. doi: 10.1038/srep04767.

Schieber, J. (1998): Possible indicators of microbial mat deposits in shales and sandstones: examples from the Mid-Proterozoic Belt Supergroup, Montana, USA. Sedimentary Geology 120, 105-124. doi:10.1016/S0037-0738(98)00029-3.

Schieber, J. (2002): Sedimentary pyrite: A window into the microbial past. Geology 30: 531-534. doi: 10.1130/0091-7613(2002) 030<0531:SPAWIT>2.0.CO;2.

Schieber, J., Arnott, H.J. (2003): Nannobacteria as a byproduct of enzyme-driven tissue decay. Geology 31, 717-720. doi: 10.1130/ G19663.1.

Schopf, J.W., Barghoorn, E.S., Maser, M.D., Gordon, R.O. (1965): Electron microscopy of fossil bacteria two billion years old. Science 149, 1365-1367. doi: 10.1126/science.149.3690.1365.

Shapiro, R.S. (2000): A comment on the systematic confusion of thrombolites. Palaios, 15,166-169. doi: 10.1669/0883-1351(2000)015<0166:ACOTSC $>2.0$.CO;2.
Spadafora, A., Perri, E., McKenzie, J., Vasconcelos, C. (2010): Microbial biomineralization processes forming modern $\mathrm{Ca}: \mathrm{Mg}$ carbonate stromatolites. Sedimentology 57, 27-40. doi: 10.1111/j.13653091.2009.01083.x.

Taylor, K.G., Macquaker, J.H.S. (2000): Spatial and temporal distribution of authigenic minerals in continental shelf sediments: implications for sequence stratigraphic analysis. In: Glenn, C., et al., (eds.), Marine Authigenesis: Microbial to Global. SEPM, Special Publication 66, 309-323. doi: 10.2110/pec.00.66.0309

Vasconcelos, C., McKenzie, J.A., Bernasconi, S., Grujic, D., Tien, A.J. (1995): Microbial mediation as a possible mechanism for natural dolomite formation at low temperatures. Nature 377, 220-222. doi:10.1038/377220a0.

Vergani, G.D., Tankard, A.J., Berlotti, H.J., Welsink, H.J. (1995): Tectonic evolution and palaeogeography of the Neuquén Basin, Argentina. In: Tankard, A.J., Suárez, P., Welsink, H.J. (eds.), Petroleum basins of South America. AAPG Memoir 62, pp. 383-402.

Visscher, P.T., Stolz, J.F. (2005): Microbial Mats as bioreactors: populations, processes, and products. Paleogeography, Paleclimatology, Paleoecology 219, 87-100. doi: 10.1016/j.palaeo.2004.10.016.

Visscher, P.T., Reid, R.P., Bebout, B.B., Hoeft, S.E., Macintyre, I.G., Thompson, J.A. (1998): Formation of lithified micrite laminae in modern marine stromatolites (Bahamas): the role of sulfur cycling. American Mineralogists 83, 1482-1493.

Warren, L.A., Maurice, P.A., Parmar, N., Ferris, F.G. (2001): Microbially mediated calcium carbonate precipitation: implications for interpreting calcite precipitation and for solidphase capture of inorganic contaminants. Geomicrobiology Journal 18, 93-115. doi: $10.1080 / 01490450151079833$.

Weiner, S., Dove, P.M. (2003): An overview of biomineralization and the problem of the vital effect. In: Dove, P.M., Weiner, S., De Yoreo, J.J. (eds.), Biomineralization. Mineralogical Society of America. Review in Mineralogy and Geochemistry 54, 1-31. doi: 10.2113/0540001.

Westphal, H., Heindel, K., Brandano, M., Peckmann, J. (2010): Genesis of microbialites as contemporaneous framework components of deglacial coral reefs, Tahiti (IODP 310). Facies 56, 337-352. doi: 10.1007/s10347-009-0207-3. 